\title{
Refazer o corpo, esculpir afetos ou o que aprendemos com Antonin Artaud
}

\author{
Martha de Mello Ribeiro \\ Universidade Federal Fluminense
}

\begin{abstract}
Resumo
O pensamento sobre o corpo se coloca contemporaneamente no centro das reflexões sobre a arte, sobre o sujeito, suas experiências, sua singularidade, em toda complexidade de nosso estar no mundo. Um corpo feito de intensidades, um bloco denso de afetos, dono de um saber que coloca em dúvida a construção de nossa subjetividade. Esse corpo ultrapassa o familiar em nós, nos atravessa, provocando experiências para além do corpo sensível. Neste ensaio, observa-se na gênese de uma cena-corpo autoficcional tentativas de insurreição e de decolonização das estruturas de subjetivação do corpo sensível, em direção à liberdade da "dança às avessas" performada por corpos impróprios, conforme nos instigou Artaud, em seu Teatro da Crueldade.
\end{abstract}

Palavras-chave: cena-corpo; Artaud; decolonização; afetos; autoficção.

"nos dirigimos aos inconscientes que protestam"

Deleuze

"eu, Antonin Artaud, sou meu pai, minha mãe"

Artaud

O modelo fabular tradicional, que se organiza em torno do fazer, do agir, da ação, se auto autoriza a produzir representações "válidas" sobre o outro, sem levar em conta, justamente, o outro, a "outridade"1. Sovando em uma organização arbitrária, um certo recorte inteligível e familiar, uma espécie de retrato do outro, seu objetivo final é legitimar um modelo de comportamento que satisfaça uma organização social. Essa organização, a priori do corpoobservado-representado, será responsável por permitir ou não a permanência deste "outro" objetivado na sociedade-organismo. O que se vê neste modelo de composição fabular é a

\footnotetext{
${ }^{1} \mathrm{O}$ ensaio foi apresentado em forma de comunicação durante o 14ํㅡㄹ Congresso Internacional de Estética - Brasil: Artes do Corpo, Corpos da Arte, durante encontro da ANPOF na Universidade Federal de Ouro Preto em outubro de 2019. Essa versão ampliada é o resultado de uma série de ajustes ao conteúdo apresentado oralmente.
} 
reprodução de uma ideia de humanidade e de sociedade, que se constrói nas bases de uma civilização colonial-capitalística-cristã, na qual todos devem servir a uma determinada função, possuir uma utilidade dentro da cadeia produtiva, que sirva ao funcionamento deste organismo, sobre as bases e regras de funcionamento deste mesmo organismo. Essa reprodução incessante, maquínica, de retratos válidos, de corpos-objetivados, funciona como detratores da diversidade e complexidade humana. Esse tradicional sistema de representação não reconhece a singularidade do outro, não estabelece conexões, zonas de confluência entre o um e o outro, sua função é reduzir toda essa multiplicidade e complexidade ao mesmo, ao espetáculo da divisão entre sujeito e objeto. Essa outridade estrangeira é capturada, domesticada, triturada e organizada disciplinarmente por este sistema, no qual servimos voluntariamente, inconscientemente. Nossa servidão voluntária ao sistema disciplinar já foi denunciada por Étienne de La Boétie (1530-1563) no século XVI, no famoso Discurso da Servidão Voluntária, que nos provoca a pensar a servidão como uma doença, um mal coletivo que atinge os corpos tornados dóceis.

Os corpos dóceis, disciplinados, permanecem alienados de si, dos seus corpos desejantes, da sua força vital criativa, servindo de forma maquínica a um desejo que the foi soprado. Um desejo fabricado artificialmente pelo sistema-organismo da sociedade (e aqui nos referimos ao mundo ocidental e ao sistema de organização capitalístico), que preenche momentaneamente nosso deserto de vida. Vida que foi consumida justamente pelo mesmo sistema necrófilo que finge nos nutrir. Claro que tal servidão é o anúncio da impotência do sujeito diante do mundo. O sistema fabrica ilusões de resposta a esse mal-estar, despejando artefatos luminosos e sedutores no sistema organismo, de modo a anestesiar a dor de uma ferida permanentemente aberta e que se aprofunda nos corpos. Apartado da vida, nossos corpos dóceis simulam estratégias para perseverar e continuam, como zumbis, a caminhar sobre a terra, devorando o outro, mas não de forma antropofágica, potente, como foi pensado por Oswald de Andrade. Os corpos zumbis, alienados de si, são os soldados do sistema. Tristes corpos que não possuindo uma narrativa para seu sofrimento, apenas seguem devorando a vida ao seu redor, devorando na própria nascente toda vida que deseja germinar. Na organização sistemática do capital, renunciar ou protestar contra o sistema disciplinar seria um ato de loucura, por isso a importância dada à disciplina, a normatização dos corpos, é isso que garante a estrutura do sistema. Voltando ao modelo de representação que institui na cena retratos servis, apagando ou encarcerando os corpos que protestam, reproduzindo a barbárie - o genocídio simulado de civilização -, pedimos licença para uma metáfora que talvez ilumine o grau de violência que o sistema colonial-capitalístico-cristão impõe ao desejo: como seria dizer a uma goiabeira para ser criativa e produzir jabuticaba para finalmente ser feliz e aceita na floresta? O organismo social é justamente a foice que devora a paisagem, a camisa de força que aprisiona a força vital, que embrutece a vida na sua nascente. 
Alguns corpos fizeram de sua vida e obra um levante contra o abuso de sua carne, Antonin Artaud (1896-1948) foi um desses homens. É para os corpos impróprios e infiéis que Antonin Artaud fez a sua obra. Obra carne, obra corpo, obra vida. O corpo impróprio de Antonin Artaud foi, é, uma arma de guerra (o bom combate) contra o controle de toda organização hierárquica disciplinar. Artaud quis salvar o teatro e a si mesmo do "real" institucionalizado, quis refazer o poder do teatro por obra da crueldade, instituindo uma cenadança às avessas: corpos sem órgãos, insubordinados. Seu projeto se constituiu em diferentes tentativas de insurreição de seu corpo, um corpo em devir-ato, refeito infinitamente para poder existir. E a via para esse refazimento incessante do corpo era apostar nos saberesdo-corpo contra toda regulagem, contra toda anatomia, contra todo estupro do "deus ladrão". Sua via para a insurreição foi fazer do corpo seu verbo, expondo uma narrativa do eu em movimento: suas experimentações nos sanatórios, o exercício carnal da escrita, as sonoridades, a onomatopeia e hieróglifos, os sopros, a respiração, os fluidos corporais, a dor e a fome tornam-se potências de refazimento e de libertação do corpo-anatômico subjugado, corpo-castrado. As imagens fulgurantes tecidas pelo poeta Artaud são o gesto de combate e resistência ao programa sistemático de extermínio dos saberes-do-corpo. Estas imagens se adensam como grumo e nos falam, em sua gagueira e complexidade rizomática, a história de Momo: crueldade, corpo sem órgãos, anatomia furtiva, peste, atletismo afetivo, sopro, carne, dança às avessas, vida, teatro, pensamento, nervos, linguagem etc., que compõe o abecedário artaudiano, foram tentativas de combate às forças do sistema que capturam e cafetinizam a força vital. O pensamento cruel como uma das linhas de força que se conectam para criar territórios nômades, armas de guerra no combate ao projeto de extermínio das subjetividades que escapam de uma subjetivação coercitiva, da normatização de um retrato legitimado, operado pela força da lei e de polícia.

Michel Foucault no livro Tecnologías del yo (2008), ainda sem tradução para o português, entende a existência como um processo estético e político, no qual o poder disciplinar cedeu lugar a uma outra estrutura de poder mais difusa, com mais capilaridade e fluidez, de difícil apreensão e por isso difícil de combater. Uma nova era se apresenta, o que ele denominou de a era da biopolítica. O biopoder, que significa literalmente poder sobre a vida, vai mais longe do que a técnica disciplinar centrada no corpo máquina e desenvolvida no século XVII (como longamente estudado por Foucault e demonstrado no $A$ história da sexualidade e outros escritos). A tecnologia de poder empregada na biopolítica toma como fonte de extorsão a própria força vital. Comprometendo nosso aparelho cognitivo ou afetivo, apropria-se de nosso potencial de criação, produzindo modos de subjetivação que direcionam as subjetividades para um modo de vida obediente ao sistema de poder dominante. Tal reflexão se soma às análises de Suely Rolnik contidas no livro Esferas da Insurreição, no qual a psicanalista e ensaísta vem confirmar que a estrutura de dominação vigente articula e 
cafetiniza o desejo em sua nascente, nos fazendo obedecer gozosamente aos processos colonizadores de dominação e de coerção do desejo. Os braços do controle biopolítico, acrescenta José Gil (2009, p. 40) a partir de suas leituras de Antoni Negri, atingem algo que está além do corpo-espécie, ou seja, o "trabalho imaterial": ideias, saber, cultura, etc., e aqui destacamos os afetos! A produção dos afetos atingida pelo programa de uma biopolítica capitalista-colonial-antropocêntrica (como a nossa) vai estabelecer formas de vidas, pensamentos e relações sociais artificialmente construídos, isto é, "vidas cafetinadas" (para usar um ótimo termo empregado por Rolnik) que recusam a experimentação de si, se conformando à modelos de pensamento e à condutas sociais previamente acertadas.

José Gil no livro Em busca da identidade, desnorte faz a seguinte pergunta: "Como se formam as subjetividades?" O interesse da pergunta é fundamental para a compreensão do poder dos afetos no projeto de refazimento do corpo, sua insurreição e potência em criar novas subjetivações que promovam levantes em resposta aos agenciamentos de uma perversa biopolítica necrófila. Gil vai explicitar, de forma clara, a engenharia necessária para a formação e produção de subjetividades "adequadas", isto é, dóceis. Referindo-se a Foucault, diz que a subjetividade é uma força de autoafecção. No entanto, diz Gil, "essa força é induzida no sujeito a partir de fora" (2009, p. 23) - conforme já nos disse Spinoza no seu estudo sobre a ética dos afetos, ao denunciar e alertar sobre os maus encontros, produtores de tristeza, que paralisam a força vital e a ação. Artaud, ao seu modo, também denunciou tal incorporação de forças externas na formação das subjetividades. Essas forças externas ao indivíduo, os agenciadores do sistema político, social, econômico e dos sanatórios, incorporados no "deus ladrão" artaudiano, força externa responsável por uma "palavra soprada" que lhe rouba, antes de nascer, os pensamentos, formam o duplo de Artaud ou a "dobra" do processo de subjetivação. Quer dizer, a subjetivação é, conforme nos diz Gil, uma incorporação de forças: àquelas externas ao indivíduo e suas forças vitais, formando assim uma dobra: "[...] entre um sistema institucional de poder e de saber e as forças do homem livre estabelece-se uma relação, de onde resultará uma captura das forças do individuo pelas forças do sistema" (idem). Esse sistema de forças constrói a estrutura fechada e logocêntrica da representação.

A captura da força vital pelo poder instituído permite ao sistema se dobrar sobre a força vital dos indivíduos, criando um dentro marcado, reconhecível. Esse dentro codificado é a subjetividade que se pretende obter com os organismos biopolíticos, nos diz Gil. Retornando à complexa questão do duplo em Artaud, o teatro estaria assim contaminado por um processo de subjetivação da sua força vital, que o submeteria à modelos de representação com a produção de corpos obedientes. O teatro da crueldade vislumbra linhas de força que produziriam corpos inadequados ao sistema de poder e aos processos de subjetivação da arte. O projeto de Artaud foi investir numa produção, por assim dizer inadequada, que 
estivesse à margem do sistema do poder institucional, um teatro que existisse para além do sistema representativo, como foi por exemplo seus experimentos com a glossolalia. Artaud começou um levante contra a sujeição de sua força vital, impondo seu corpo contra toda ideia de utilidade e significação, denunciando com seu sangue, ossos e nervos o genocídio legitimado pelo sistema de representação. Contra as forças disciplinares de controle, contra os métodos e objetivos de um estado polícia, contra a medicação, psiquiatria, jurisdição, contra a higienização e subordinação de sua carne, Artaud nos entregou seu corpo indisciplinado ou como denominamos, impróprio. Um corpo produz experimentando-se, esculpindo afetos, transfigurando-se num gesto de retomada contra os processos biopolíticos de controle. Concubina de uma sociedade disciplinar, organizada na fabricação e conservação de corpos dóceis, o sistema de representação exige uma ideia de normalidade que implica o fechamento da complexidade do real, agindo como se não existisse a possibilidade de construir novas vidas ou novas ideias de mundo. Os corpos impróprios que desobedecem a organização desse estado polícia desafiam, com a indiscrição de sua carne, nosso imaginário, desvelando diante de nós, através de seus corpos extravagantes e plurais, um caminho para a liberdade. Um recomeço. Eis a palavra de Artaud, em Cinco cartas a André Breton (1947):

[...] é que a massa não me perdoa. Sabendo como as consciências se aproximam, uma da outra, através dos espaços, aprendi também a surpreendê-las, a observálas bem, a escutá-las e a vê-las. [...] O corpo humano atual é um inferno com o qual se atracaram todas as magias, todas as religiões, e todos os ritos para esclerosar, atar, petrificar, amarrar dentro do módulo de suas estratificações atuais, que são o primeiro verdadeiro impedimento a toda verdadeira revolução. (ARTAUD, 2017, p. 131-133).

As palavras de Artaud são contundentes quanto a necessidade da libertação dos corpos para uma "verdadeira revolução", é somente através desta micropolítica dos corpos que algo novo pode vir a acontecer. E, além disso, denuncia a complexa aproximação de "consciências", organizadas nos espaços e territórios, que a partir do reconhecimento identitário se aglutinam para neutralizar as intensidades que não correspondem ao modelo legitimado pela perspectiva da representação. É clara a posição de Artaud de rejeição ao plano identitário, baseado no reconhecimento, pois todo reconhecimento é ao mesmo tempo divisão e conservação. Elas (as consciências), vai nos dizer o poeta, "se aproximam, uma da outra, através dos espaços". Toda aproximação de corpos produz uma certa composição que nos acomete, fundando novas conexões que agitam e abalam nossa subjetividade. Tal afirmativa retorna contemporaneamente nas palavras do coletivo francês Tiqqun: "o que 
acontece entre os corpos numa ocupação é mais interessante que a ocupação em si"2 e também nas palavras da ensaísta e psicanalista Suely Rolnik, ao sustentar que as forças que estão no mundo nos acometem, nos engravidam. Em suas palavras: "Somos povoados por uma infinidade variável de ambientes, atravessados por forças/fluxos de todo tipo" (1995, p. 1). Essas forças que nos atravessam, pela via da experiência, produzem múltiplas diferenças, rasgos de estranheza na zona de conforto de nossa familiar subjetividade. $O$ atravessamento dessas forças diz que algo singular nos acometeu, ocasionando um mal-estar irreversível, que nos faz tremer, que abala todo o sistema de reconhecimento, nosso modo de existência, fazendo desaparecer o nosso mundo, sob nossos pés. É na dor (na crueldade, no sentido artaudiano) que nos chega o prenuncio de que algo novo pode vir a nascer. Para isso, é necessário o salto no caos de nós mesmos.

Mas não é tão simples assim, se concordamos com Rolni na sua análise de que nosso modo de subjetivação serve, gozosamente, ao abuso, à cafetinagem do regime colonial capitalístico. Pois nesse sistema organizado pelo capital neoliberal, nossa potência vital é obstruída desde sua nascente, pelo lixo acumulado do sistema de informação e de representação. Entra em cena, nessa convulsão e atualização de nós mesmos, o temor em nos abandonarmos à forças desconhecidas. E uma das reações possíveis é a obstrução do jorro de vida, que a eclosão da diferença poderia nos proporcionar. Obstruída a vida, voltamos a nos agarrar, e novamente cito Artaud, no "módulo de nossas estratificações atuais, que são o primeiro verdadeiro impedimento a toda verdadeira revolução". O que Artaud buscou, em sua desesperada e radical experimentação de si, foi desfazer de forma vertiginosa qualquer possibilidade de cristalização identitária, levando as últimas consequências o projeto de insurreição de seu corpo, de construção experimental de si. Afirmando, sem nenhuma contemporização, as exigências das múltiplas, complexas e diversas potências que o atravessavam ao mesmo tempo. Não resistindo a força multidirecional e centrifuga do jorro das diferenças, Artaud, o momo, foi longe na acepção do caráter trágico de nossa existência. Sempre um rascunho de si mesmo, se imaginou pura produção de diferença, infinitamente, se negando a reconhecer sua condição de humano e a inexorável finitude dos modos de existência. O teatro da crueldade pensado por Artaud é a impossível tarefa de expor em linguagem um modo de experimentação de si sem concessão, de abolição de todo contorno, de todo reconhecimento. Uma experimentação que levou Artaud, ator-criador-cruel de si, a um lugar que ultrapassa o humano, absorvendo em seu corpo toda a complexidade do grumo formado pelo acúmulo das diferenças. Mas seu teatro da crueldade e sua concepção para um corpo sem órgãos também foi a tentativa de criar as condições para produzir vida, decantada

\footnotetext{
2 Disponível em: https://laboratoriodesensibilidades.files.wordpress.com/2019/05/como-fazer-como-desertartiqqun.pdf
} 
a partir deste jorro das diferenças, na intrínseca vocação do teatro em representar. Os hieróglifos, a glossolalia, a experimentação dos sons e palavras, os exercícios de respiração executados por Artaud nos sanatórios foram os elementos de ancoragem para o retorno de Artaud ao humano, para o refazimento de seu corpo em representação (ainda que sempre em devir).

Suas experimentações artísticas, literárias, sonoras e cênicas foram a tentativa de sustentação para seus devires. Um modo de subjetivação e de estruturação, ainda que sempre processual, para um corpo incontornável. Seu trabalho radical de experimentação, pela via da arte, foi sempre a tentativa e o fracasso de criar para si um corpo furtivo (para usar uma expressão de Artaud), uma espécie de autômato ou fantoche, que se colocasse ali, onde não havia mais o si mesmo, mas o indefinido outro de si. Num livro atual sobre Antonin Artaud, publicado e traduzido no Brasil em 2011, chamado Eis Artaud, a autora Florence de Mèredieu nos confessa a impossibilidade de traçar uma biografia sobre o poeta, justamente porque a própria ideia de biografia vai contra a corrente de tudo que Artaud lutou em vida. Artaud via a história como balizas incômodas, limitadoras da complexa criação de seu imaginário, um organismo a serviço de uma identidade já nascida calcinada: "Antonin Artaud foi primeiramente um modelo pervertido, uma tentativa de esboço que eu mesmo retomei em certo momento para entrar em mim vestido" (obras completas, XVI-42). "Entrar vestido" em mim, diz o poeta, luminosa imagem que evidencia sua crítica a toda história ou biografia que, anterior a todo nascimento, tenta dizer, balizar uma certa ideia (pensamento) sobre nós. Podemos ampliar ainda mais a extensão de sua crítica aos corpos vestidos ou colonizados, dizendo que o "modelo pervertido" de nome Artaud trata-se de um corpo dócil, disciplinado pelo sistema de representação. Muito mais do que nossa força de trabalho, o sistema se mantém funcionando colonizando nosso imaginário, atribuindo, validando, legitimando suas próprias representações. A autora, ao assumir o fracasso da tentativa biográfica, ao mesmo tempo nos confirma sua necessidade, entendendo nos detalhes biográficos acumulados pelo caminho, mais do que simples balizas, o "borbulho" de um imaginário que precisa vir à luz: "levar em conta esse rasgo do imaginário que consome constantemente o tecido serrado da realidade" (2001, p. 32). As ressonâncias da obra-vida de Artaud apenas começaram, seus embriões estão preservados e prontos para germinar.

A produção de arte também não escapa a esse trabalho e economia do biopoder, como por exemplo as formas de arte representativas que, gerenciadas pelo mercado cultural, produzem uma arte corpo-cultura que reafirma os modos de subjetivação ditados pelo sistema de controle vigente, produzindo, como dirá Artaud, uma arte morta, comportamental, mas com alto valor mercadológico. Sua obra é um bisturi afiado que penetra no tecido da realidade, desviando e subvertendo sua lógica. Esse bisturi é feito da ética do desejo, se faz na escuta do corpo e seus saberes. O trabalho de Antonin Artaud, em sua disposição para se conectar 
ao corpo, esse corpo sem órgãos, nesta radical experiência fora do sujeito, traz para a arte do ator uma abertura fantástica aos possíveis. O ensaio "Um atletismo afetivo", escrito pelo poeta ao final de 1935, descreve o ator como um "atleta do coração", aquele que em seu processo de trabalho "exercita" não os músculos, mas os afetos (no sentido de afectar). Palavras que instigam o ator a se lançar numa busca experimental, improvisacional, intuitiva ${ }^{3}$ e rigorosa de escuta do corpo, do que ele tem a dizer, a ensinar, fora da experiência do sujeito. A obra viva de Artaud nos ajuda a pensar a arte da cena como território processual para reativar essa escuta do corpo, uma escuta que a cultura ocidental, com seus arranjos e dispositivos, tenta silenciar, concentrando e validando a experiência na centralidade do sujeito, no aspecto perceptivo, sensorial da vida concreta, escravizando o desejo na representação. A criação como um ato de guerra, um levante contra a ordem disciplinar instituída e seu projeto biopolítico de extermínio, em seus mais diversos níveis. A criação se investe como força que se distingue e que ultrapassa todo poder externo a ela. Nas palavras de Artaud:

Toda a criação é um ato de guerra: guerra contra a fome, contra a natureza, contra a doença, contra a morte, contra a vida, contra o destino. [...] Não defendo as artes da paz. Criar em paz é uma atitude burguesa e se sou contra todas as atitudes burguesas é porque tenho uma verdadeira noção do espírito de propriedade. A fome, o frio, o amor, a doença e o sono não são coisas das quais possamos retirar prazer artístico. Não sou a favor de que os artistas devam procurar esse prazer à custa do frio, fome e sono. Não aceito que os artistas possuam individualmente as suas próprias satisfações porque sou contra o espírito de propriedade, contra 0 espírito de posse em todos os planos possíveis. (ARTAUD, 2004, p. 734).

Nos aproximando da ideia de Artaud, nossa aposta neste ensaio é pensar a cena contemporânea na complexidade dos afetos, à partir do que acomete (afecta) nossos corpos nos processos de produção de subjetivação. A ideia artaudiana de refazimento do corpo é, para nós, um possível território para se enfrentar os múltiplos agenciamentos do desejo, de nossa força vital. A via para esse enfrentamento é, sem dúvida, a criação. Aliando conceitos como experiência, mapa de afetos e decolonização, junto a uma rede de experimentações do corpo pela via da autoficção e das escritas de si, interroga-se: como o corpo se investe de potência criativa, para o estabelecimento e afirmação de um saber próprio, singular, desestabilizador de identidades e de processos de subjetivação? Entende-se o corpo como uma força, um campo de afetos, capaz de desobstruir a via de acesso para a construção de um "comum". Construir um "comum" é exercer um trabalho de reapropriação coletiva da potência de criação, que há séculos se vê usurpada por múltiplos agenciamentos biopolíticos.

\footnotetext{
${ }^{3}$ A partir de Spinoza e Deleuze, entende-se intuição como um método complexo irredutível à inteligência ou ao instinto. A intuição como método é fundamental para compreender o rigor dos processos artísticos e produção de conhecimento, aproximando a pesquisa da criação e a afastando da sistematização cientificista como pré-requisito para o conhecimento. A pesquisa pelo método intuitivo se apresenta como experimentação contínua.
} 
Investiga-se novas cartografias e linhas de fuga que nos ensinem a nos "juntar", como forma de resistência às práticas coloniais e fundamentalmente a uma perversa ordem de microrracionalidades, de pequenos lotes de grupos de indivíduos que recusam ao compromisso coletivo: "reféns da imagem de 'domínio racional' sobre a natureza humana, a identidade e o destino; e de uma racionalidade de vida artificial, projetada, monitorada e reflexivamente melhorada" (BAUMAN, 2011, p. 236).

Buscamos lançar a perspectiva de que o corpo é, potencialmente, um agente capaz de esculpir afetos, de construir uma rede de afecções outra que escape à "dobragem" das formas de poder em nossa força vital. Esculpir afetos seria, em nosso entendimento, uma ação eficaz e consciente, impulsionada pela força vital contra à incorporação passiva de nossas forças internas. Esculpir afetos, ou refazer o corpo, é uma ação criativa que se coloca ao avesso dos processos maquínicos de subjetivação, reprodutores de subjetividades pré-concebidas, adequadas a uma determinada função, lugar ou comportamento. O corpo, como escultor de afetos, aponta a linha de fuga dessa complexa adequação do desejo a formas pré-concebidas, se contrapondo à economia de um corpo dócil, tornando-se por fim um corpo impróprio. Neste ponto do ensaio, destacamos, dentre as múltiplas possibilidades na cena contemporânea de ações criativas que buscam a via de refazimento do corpo, ou de decolonização do pensamento: a produção autoficcional. Entende-se que a autoficção e as narrativas de intimidade permitem e propõem um espaço outro para o acontecimento, na dilatação e nas rasgaduras das últimas fronteiras entre o real e a ficção, conformando em tal espaço memórias, documentos, afetos e desejos como invenção e produção.

Em nossa hipótese, tal rasgadura se coloca como estratégia micropolítica aos agenciamentos que o sistema representativo, na sua perversa manipulação do desejo, tem impetrado como modelo hegemônico de orientação de mundo e modelo cultural. Proporcionando novos lugares de fala e promovendo encontros afetivos "de verdade", no qual o ator lança mão, como estratégia de atuação, a confissão. Na tecitura de sua realidade e sua intimidade, acentua-se o olhar para a geografia de corpos dissonantes e para o acontecimento num projeto ético-político-estético para um estar junto, contribuindo com a ideia de um "comum" feito de singularidades. Um teatro que se coloca como resistência micropolítica aos processos de subjetivação dominantes. Ivan Isquierdo, durante conferência da ABRACE (Associação Brasileira de Pesquisa e Pós-graduação em Artes Cênicas) em 2012, diz: "Somos o que realmente lembramos ter sido e somos" (IZQUIERDO, 2012, p. 20). A memória é entendida como um corpo que trabalha, imprimindo nossa singularidade e resposta ao mundo. A memória é o resultado do encontro furtivo entre corpos diversos, vozes, olhares e escuta acumulados e atravessados ao longo do tempo. Memória não se compõe por fatos incontestáveis e nem mesmo é rememoração, ela é escrita performática, é ação criadora que provoca realidades de nós mesmos e do mundo que habitamos. E nesta complexa tessitura 
do real, comparece os afetos e o sonho. E o sonho é linguagem que escapa ao controle disciplinar da representação. Nos aproximando das considerações de Antonin Artaud, entendemos o sonho como o avesso de toda cena da representação. O teatro da Crueldade pensado pelo artista, em nosso entendimento, descortina o caminho para desobstruir o acesso a uma cena de tensionamento entre o estranho e o familiar. E o teatro autoficcional e das narrativas íntimas na contemporaneidade vem hipertrofiar essa cena às avessas e de embaralhamento entre real e a invenção, embrionariamente apontadas por Artaud, lançando os dados para a denúncia de toda arbitrariedade do pensamento, de toda arbitrariedade representativa, a partir de uma ideia do sonho (ou invenção) do eu.

A partir dessas reflexões, desenvolvo a ideia da experiência enquanto um corpo vivo, atravessado pelos efeitos de uma cartografia social, cultural e política e ao mesmo tempo capaz de criar novas possibilidades de intervenção no mundo. Formas mais potentes de existência, pois mais afins ao desejo em seu impulso de germinação de novos mundos. A autoficção e as escritas de intimidade, como o Biodrama, nos parece um excelente dispositivo artístico para os processos de decolonização dos corpos, justamente por provocar um trabalho de experimentação de si, que exige uma constante atenção ao mapa dos afetos do corpo. Como afirma Cornágo: a "verdade de um corpo nos afeta, ainda que se resista a ser compreendida, antes mesmo que a história seja referida através de palavras" (CORNÁGO, 2009, p. 101). Escutar nossas experiências, ativar nossa escuta para os saberes do corpo e nossas fragilidades às forças que nos atravessam nos parece o caminho para a desobstrução de nossos desejos e para a decolonização de nossos corpos. A pesquisa, em sua dimensão prático-reflexiva, entende o estar junto como combate estético aos agenciamentos de controle de nossa força vital. A investigação prática/experimental se desenvolve no âmbito do Laboratório de Criação e Investigação da Cena Contemporânea da Universidade Federal Fluminense ${ }^{4}$. O escopo do projeto é pensar essa complexidade dos afetos, à partir do que acomete (afecta) nossos corpos nos processos de produção de subjetivação, e com os experimentos de autoficção transmutar esses corpos, sem denegar nossas fragilidades, em um novo corpo mais potente, pela via de uma constante experimentação de si. Nossa hipótese é entender a autoficção e os processos de decolonização como um saber próprio ao corpo, isto é, um conhecimento que emana do e no corpo, lançando os dados para a denuncia da arbitrariedade dos processos de subjetivação e seus modelos de representação.

A experimentação de si e a experimentação na arte são trabalhos investigativos que somados, na criação autoficcional, podem retomar, ainda que de forma sempre instável, a

\footnotetext{
${ }^{4}$ Criado em 2010, o Laboratório desenvolve suas atividades no âmbito do Departamento de Arte e no Programa de Pós-Graduação em Estudos Contemporâneos das Artes da Universidade Federal Fluminense. Esse ano, em função da pandemia, o projeto "Escritas do corpo" em sua dimensão pratica, foi desenvolvido todo de forma remota, produzindo uma série de videos curtos.
} 
força vital do sujeito e da arte, nela assim amalgamados. É neste duplo experimento que vislumbramos a autoficção como terreno fértil para novas redes para a criação de um comum, paralelo ao biopoder de mais valia. Os processos e a produção autoficcional nos parece ser esta via para a construção de novas cartografias e linhas de fuga que nos ensinem a nos "juntar", como forma de resistência aos agenciamentos e às práticas coloniais e abertura para um horizonte de novas insurgências, possibilitando a abertura de uma complexa e diversa rede de afetos, que se conecta a experiência do estranho-familiar. O espaço biográfico tem, notadamente a partir dos anos 90, invadido os palcos, propondo novos arranjos de escritura e de cena. Neste novo território fica à margem as grandes histórias, as grandes narrativas, e entra em cena, literalmente, histórias de intimidade. Essas pequenas histórias, reais e ficcionais, fazem, além de um curto-circuito de percepção, emergir uma nuvem de afetividade que instala novamente um "eu-corpo": um eu-corpo fantasmado, borrado em suas fronteiras, um eu-corpo multidimensional que se conecta com outros corpos pela via da empatia do banal, do mais simples, do testemunho, incitando devires de si. Essa trama de intersubjetividades, intrasubjetividades e trans-subjetividades, escrita neste território autoficcional, sobrepõe público e privado, real e ficção, transfigurando a cena, para um além de si mesma. Cada vida particular encenada neste "teatro do real" se estabelece como o sintoma de uma inquietude existencial. O teatro autoficcional, ao inventar devires do eu, propõe na articulação dos afetos, a libertação dos corpos deste corpo-anatômico, corpocastrado pelo sistema de regulagem. $O$ teatro autoficcional e as narrativas de intimidade podem criar um território de combate e resistência ao programa sistemático de aprisionamento do sujeito.

$\mathrm{Na}$ ideia de inquietude existencial, novamente recorremos a Artaud, nas denúncias e provocações sobre nossa servidão ao organismo disciplinar e coercitivo das regras impostas pelo sistema de representação. As influências de Artaud sobre o teatro contemporâneo, e não somente, são incontestáveis. As perspectivas lançadas no seu $O$ teatro e seu duplo, publicado em 1938, proclamam a ideia de que o teatro é ação, mas ação cruel sobre si mesmo, única forma de escapar as engrenagens e estratégias de usurpação e fechamento sobre si. "Palavras sopradas"... vai dizer Derrida no artigo "A palavra soprada" (1965) ao pensar Artaud. Palavras comprometidas com um pensamento hegemônico, que roubam nossa força e potência vital, que nos impedem de agir, que nos aprisionam em representações, conservando a vida em exemplaridades. Artaud condenou todo corpo-organismo como corpo servil ao espetáculo da imitação, condenando todo pensamento separado da vida. Sua proposta foi a libertação, a insurreição dos corpos, contra um deus ladrão que nos furta desde o nascimento. O Teatro da Crueldade, proposto pelo artista, conclama o fim do fechamento da representação: contra todo fechamento, a experimentação de si, o refazimento incessante do corpo, isto é, uma nova plasticidade mental e corporal, como possibilidade para o início do 
processo de decolonização de nossas forças. A via para esse refazimento incessante do corpo será apostar nos saberes/afetos-do-corpo que na ética de afirmação da vida se põe contra os efeitos entristecedores de todo ato de regulagem. O teatro autoficcional e as narrativas de intimidade, como o Biodrama, se entende enquanto território de combate e resistência ao programa sistemático de aprisionamento do sujeito e aos múltiplos agenciamentos que nos atravessam.

O trabalho Las Personas (2014) da artista argentina Vivi Tellas é um ótimo exemplo da potência micropolítica de que pode se valer o teatro. No gesto de colocar em cena os trabalhadores do Teatro San Martin, apresentando suas histórias de vida e de trabalho, a diretora põe ao avesso toda a estrutura teatral. Quando pensamos no teatro ou quando assistimos à um espetáculo teatral, dificilmente refletimos que os trabalhadores e técnicos que fazem o "show" acontecer, também fazem parte do acontecimento. Esta complexa comunidade do sensível que é o teatro, existe neste estar junto, com os técnicos, os atores e o público. É sobre essa comunidade do sensível que Las personas vem a nos ensinar, investindo contra os lugares prefixados, tornando mais intensa nossa experiência de convívio no teatro. Se o teatro não pode mudar a realidade, pode promover sua problematização e seu questionamento, com gestos como esse: atitudes críticas e criativas que nos façam detectar questões que merecem nossa atenção: a importância da democratização do sensível, de pensar o teatro enquanto um "comum", um território formado por artistas, técnicos e público. Las Personas nos convida à pensar sobre essas e outras relações invisibilizadas pelo sistema de representação, expondo a cartografia da realidade teatral e nossa estrutura social. 0 avesso da cena provoca a desestabilização das certezas inerentes à toda esfera de poder, neste caso, do teatro como sendo um acontecimento entre o ator, o diretor (ou dramaturgo) e o público somente. O espetáculo nos faz ver toda uma comunidade de corpos, outras sensibilidades que são sistematicamente silenciadas. Sobre o teatro: como já dizia Augusto Boal, "Todas as pessoas podem fazer teatro, até os atores!" (1980, p.29). O teatro pode atuar questionando as maneiras estabelecidas de fazer teatro e de ver o mundo, refutando modelos e as "divisões do sensível" (para dizer como Rancière em A partilha do sensível, 2009) . Esse é um dos gestos políticos do Biodrama e do experimento Las Personas: ampliar o campo do sensível e abrir espaços para novas subjetividades, novos pontos de vista, como a dos técnicos do teatro.

Em nossa hipótese, o Biodrama se põe como estratégia micropolítica aos agenciamentos que o sistema representativo, na sua perversa manipulação do desejo, tem impetrado como modelo hegemônico de orientação de mundo e modelo cultural. proporcionando novos lugares de fala e promovendo encontros afetivos inusitados, como se deu em Las personas. O umbral mínimo da ficção, detectado por Vivi Tellas, acentua a ideia do teatro como acontecimento, como cena ética, política e estética para a experiência de um 
estar junto, contribuindo com a ideia de um "comum". O interesse do gênero Biodrama pela história dos anônimos nos parece um caminho nessa importante direção. Na sua proposta de compartilhamento e invenção da intimidade, não somente na radical transgressão das fronteiras da ficção e do real, mas principalmente na abertura para um horizonte de novas insurgências. O teatro lança assim os dados para a denuncia de toda arbitrariedade dos processos de subjetivação que organizam o sensível.

As ressonâncias da obra-vida de Artaud apenas começaram, seus embriões estão preservados e prontos para germinar.

\section{Referências}

ARTAUD, Antonin. A perda de si: cartas de Antonin Artaud. Tradução: Ana Kiffer e Mariana Patrício Fernandes. Rio de Janeiro: Rocco, 2017.

ARTAUD, Antonin. O teatro e seu duplo. Tradução: Teixeira Coelho. São Paulo: Martins Fontes, 2006.

ARTAUD, Antonin. Oeuvres. Paris: Quarto Gallimard, 2004.

BAUMAN, Zygmunt. Vida em fragmento. Rio de Janeiro: Zahar, 2011.

BOAL, Augusto. Stop: c'est magique! Rio de Janeiro: Civilização Brasileira, 1980.

BOÉTIE, Etienne La. Discurso da servidão voluntária. Tradução: Casemiro Linarth. São Paulo: Martin Claret, 2009.

CORNAGO, Óscar. Atuar "de verdade". A confissão como estratégia cênica. Tradução: André Carreira. Urdimento - Revista de Estudos em Artes Cênicas, Florianópolis, v. 2, n. 13, p. 99-111, 2009.

DELEUZE, Gilles; GUATTARI, Felix. Mil platôs: capitalismo e esquizofrenia: vol. 1. Rio de Janeiro: Editora 34, 1995.

DERRIDA, Jacques. A escritura e a diferença. São Paulo: Perspectiva, 1971.

FOUCAULT, Michel. O corpo Utópico. São Paulo: N-1 Edições, 2013.

FOUCAULT, Michel. O que é um autor? Lisboa: Vega, 2002.

FOUCAULT, Michel. Tecnologías del yo y otros textos afines. Tradução: Mercedes Allendesalazar. Buenos Aires: Paidós, 2008.

GIL, José. Movimento total: o corpo e a dança. São Paulo: lluminuras, 2013.

GIL, José. Em busca da identidade, o desnorte. Lisboa: Relógio D’água, 2009.

ISQUIERDO, Ivan. Conferência de Abertura. In: ISAACSSON, Marta (coord.). Tempos de memória: vestígios, ressonâncias e mutações. Publicação originada do VII Congresso da Associação Brasileira de Pesquisa e Pós-Graduação em Artes Cênicas. Porto Alegre: ABRACE, 2013.

MEREDIEU, Florence. Eis Antonin Artaud. São Paulo: Perspectiva, 2011.

RANCIÈRE, Jacques. O desmedido momento. Serrote, n. 28, 2018.

RANCIÈRE, Jacques. A partilha do sensível. São Paulo: Editora 34, 2009.

RIBEIRO, Martha. Teatros do real e a abertura da representação. Urdimento - Revista de Estudos em Artes Cênicas, Florianópolis, v. 1, n. 37, p. 344-355, abr. 2020. ISSN 2358-6958. Disponível em: http://www.revistas.udesc.br/index.php/urdimento/article/view/1414573101372020344. Acesso em: 22 abr. 2020. DOI: https://doi.org/10.5965/1414573101372020344. 
RIBEIRO, Martha. Corpos impróprios e corpos reais: da crueldade ao doce extermínio da cena da ilusão. In: FLORY, Villibor; MIRANDA, Célia Arns de; ALVES, Lourdes Kaminski (org.). Dramaturgia e teatro: a cena contemporânea. Maringá: EDUEM, 2019. p. 171-186.

ROLNIK, Suely. Esferas da insurreição, notas para uma vida não cafetinada. São Paulo: N-1 Edições, 2018

ROLNIK, Suely. Esquizoanálise e Antropofagia. In: ALLIEZ, Éric. Gilles Deleuze: uma vida filosófica. Coordenação de tradução: Ana Lúcia de Oliveira. São Paulo: Editora 34, 2000. 